\title{
A 'superstorm': when moral panic and new risk discourses converge in the media
}

\section{Anita Howarth}

\section{Abstract}

Conventional approaches to mediated scares have tended to compartmentalize approaches and either use moral panic or new risk type of frameworks to analyse journalistic discourses. This article reformulates recent work on both into a conjoint theoretical way forward that allows for the possibility that moral discourses and health/environmental harm discourses may converge in the same media spaces at the same time and on the same issue. This is then explored empirically by asking how both types of discourses were used in the editorials of four newspapers that campaigned against GM food policy in the late 1990s. This is an interesting case not only because it entailed particularly intense media and public reactions; but also because the former developed in the absence of the type of concrete details journalists usually look for in risk stories, for instance, graphic images of oil-covered birds or BSE-befuddled cows. A particular media logic needed to be developed to be overcome these obstacles before a scare could be constructed around convergent moral panic and new risk type discourses. What resulted was media 'superstorm' - a term coined here to refer to sustained, intense coverage in which moral panic and new risk types of discourse converge in highly emotive, evocative and mutually reinforcing ways. When these resonate with a highly sensitized context the result is acute anxiety, social volatility and the potential for the disruption of policy and for social change. This is, the paper argues, what happened with GM food. Key words: moral panic, new risk, media logic, food scare, GM food 


\section{Introduction}

The first GM food launched on the UK market early in 1996 did not initially engender a scare. There was some moral disquiet and some direct action by a handful of protestors but little mention in the newspapers of any possible adverse health implications from it. The industry was able to claim the launch of the new product had been broadly successful. GM tomato paste outsold the conventional product and initial media coverage was sporadic, fragmentary and contradictory. By the end of 1997, environmental and consumer NGOs were warning of an imminent 'deluge' of unlabelled GM soya and maize onto supermarket shelves (Genewatch 1998). Even this failed to persuade newspapers to engage with the debates (see Howarth 2010). This changed in mid-1998, triggered first by Prince Charles in an article which newspapers claimed expressed 'widely held fears' and public scepticism about the safety/benefit claims of the proponents (see Daily Mail 1998a; Express 1998a). The second trigger was the intervention of Professor Pusztai who claimed in a television documentary that preliminary research had found that the consuming of GM potatoes had compromised the immune systems of laboratory mice (Daily Mail 1998b; Express 1998b).

These two interventions galvanized newspaper engagement. The volume of coverage increased and for the first time since the launch of GM food they committed scarce space on editorial columns to expressing the particular view of the newspaper on the issues. Previously fragmented, contradictory coverage of GM food coalesced into a more coherent, collective scepticism about the novel food particularly in the four newspapers analysed here. This hardened in the second half of 1998 into opposition first towards the technology, then against the American biotechnology company Monsanto and the British government who were seen as promoting GM food and crops contrary to the wishes of the public and in spite of uncertainty about its health and environmental effects. By February 1999, sales of labelled GM food had collapsed (Austin \& Lo 1999) in a de facto consumer boycott and four newspapers launched self-labelled campaigns advocating policy change in the form of a moratorium on cultivation and comprehensive labelling. Over the new few months a de facto retailer boycott emerged as food retailers announced GM-free policies for their own brands (see Genewatch 2000) and Monsanto acknowledged an 'on-going ... societal-wide collapse of support' for GM food and crops (Grocer 1998). 
The government felt unable to grant any new licenses and sought various means to neutralize newspaper campaigns.

What had emerged was a major mediated scare: what this article calls, a 'superstorm', in which moral discourses and health/environmental harm discourses converge in the same spaces contributing to acute anxiety and social volatility. It empirically explores how these discourses converged and the conditions that facilitated the development of a superstorm. In so doing it responds to calls by Tulloch \& Zinn (2011) for more engagement between media studies and sociology of risk. The approach taken here draws on recent studies in which some scholars have broadened moral panic thesis in ways that include environmental/health scares thus potentially bringing it closer to new risk theory. The article also brings new risk theory closer to moral panic approaches by adapting the Tulloch \& Zinn (2011) suggestion that analysis be grounded in the conceptualization of media logic to consider how the manifestation of this in campaigns shaped newspaper engagement with issues that were not on the face of it readily accessible news stories.

\section{Risk Communication, Sociology and Media}

Traditionally scholars have viewed risk communication in the instrumentalist sense of what was needed to support rational government responses to adverse media/public anxiety and so safeguard particular interests and ends (see Wardman 2008). The idea was that knowledge of how risk messages are amplified (SARF) or how the public processes risk information (psychometric studies) could be used to shape government responses aimed at maintaining or restoring confidence in risk governance. These ends were often tied to safeguarding strategic industries particularly chemical, pharmaceutical, nuclear and biotechnological. However instrumentalist approaches have been critiqued for neglecting how responses to risk and uncertainty are shaped by institutions and (historically rooted) social, culture and political contexts (see Zinn 2008). They have also tended to ignore the normative dimension of risk debates, for instance, in moral discourses of threats to values or ones that assume a democratic right to information and public right to informed consent over risks to which the individual is exposed (see Wardman 2008). Furthermore some instrumentalist approaches - in particular SARF - draw on transmission understandings of communication in which risk messages about 
objective hazards are amplified while passing through different signal stations. This has been critiqued as outdated, ignoring 30 years of media research on the complex ways in which texts are shaped in and through production processes (see Murdock et al 2003).

A more compatible research trajectory for understanding the role of the media in risk debates and social change lies in socio-cultural and sociological perspectives. These assume risk or risk discourses are a condition of late modernity so endemic. What is seen as a risk is not just a response to objective reality but is transformed and mediated through processes of communication (see Douglas \& Wildavsky 1983) or is socially constructed, brought into being and managed as part of social power (see Beck 1986). This article is located in the latter sociological-constructionist approaches and in particular Irwin's soft constructionism. This does not deny the reality of environmental - or health - problems 'but both real and imaginary ... [ones] need to be socially constructed if they are to find a place on the environmental agenda' (Irwin 2001: 21-22). The sociology of risk is concerned with general social change around such constructions of risk and these approaches, at least at the level of grand theory, afford media a central role not only in how risk is understood but also in shaping public debate and potentially challenging government policies.

However, as Tulloch \& Zinn noted, despite early calls in the 1990s for more engagement, only 'sporadic' attempts have been made to bring together the sociology of risk and media studies so that in practice the two are 'still rather separate fields ... [with] little engagement between them' (2011: 1). Risk theory, they argue, would benefit from understanding how texts can ground grand theories in everyday processes of meaning-making but have been hindered in doing this by neglecting media logic, that is, the professional practices that shape how news is constructed beyond the information passed on by sources (2011: 13). Conversely, the 'micro analysis of news production [and texts] can lack the distance to understand how the processes that deliver these contribute to a larger picture of social order and change' (2011: 13). The issue though is how to conceptualize the relationship between media and wider society. Media are not only central institutions in society they are also embedded in it so their exercising of symbolic power is derived from this embedding and shapes it. Symbolic power is the 'capacity to intervene in the course of events and shape their outcome, as well as the capacity to influence the actions and beliefs of others, by means of the production and 
transmission of symbolic forms' (Thompson 2000: 246). This operates not as the transmitting of messages but as a dialectic. Events rarely originate with the media but in wider society. In making sense of these journalists draw on wider social debates to construct their own meanings and in so doing they not only take a position in debates and in relation to events they also have the potential to shape these and with it social change. Risk debates are shaped by how the risk is constructed and two common forms are moral panic and new risk both of which afford the media central roles.

\section{Moral panic and new risk: Linear progression, co-existent or convergent sites}

Both social theories of moral panic and new risk are concerned with how threats are constructed in late modernity in ways that come to be associated with heightened or exaggerated social anxiety. Both afford media central roles. Both are concerned with the relationship between media, government and society. However, their origins are different and their classic definitions of risk diverge quite fundamentally so most studies have tended to focus on one or the other, the implicit assumption being that they are two fundamentally different phenomena. More recent studies point to how with social change these may converge.

\section{Moral panic thesis}

Moral panic theory emerged out of an intellectual response to social, cultural and political conflict in the late 1960s and a re-thinking of deviancy and moral disturbance (see Young 2009, Garland 2008). Classic approaches are concerned with the exaggeration of moral threats posed by 'deviant' cultures to the core values of a society and the stigmatizing of the 'folk devils' by a 'control culture' (see Cohen 1972; Hall et al 1978). Core values are defined by 'moral entrepreneurs' - state, media and religious organizations - who come together to erect 'moral barricades' to protect intrinsic values against the moral threat and use 'accredited experts' to give credence and legitimacy to the control measures instigated. Traditionally these approaches have assumed hegemonic relations in which the media and the state and other 'moral entrepreneurs' - work together, 'amplifying deviance and orchestrating social reactions so that the panic becomes a consensus-generating 
envoy for the dominant ideology' (Ungar 2001: 284). A media-state consensus forms because the wider hegemony that both subscribe to is perceived to be in crisis in the sense of a 'disintegration of consensus' so the intervention of these two major actors is intended to arrest this (Young 2009: 13).

There has been a massive output of research on moral panics and in the process considerable debate over what is moral, what is panic and what the relationship to the hegemon is (David et al 2011: 216). The theory still draws attention away from the 'deviant' onto the definers of this and onto the relations of power. Beyond that there are major differences between those who, on the one hand, argue for a narrow definition of the key terms and the continuation of the classical precepts (see Crichter 2003, 2011), and on the other hand those who argue the nature of society and panics have changed so the conceptualization needs to be broadened to accommodate this (see Cohen 2011). This article is located within the latter tradition because it is this one that is potentially more open to the possibility that moral panic and new risks can converge or co-exist.

This broader approach has a number of implications for this article. It challenges the view that health or food scares cannot be moral panics because they 'do not fit the model' where the focus is on marginalized groups labelled as 'deviant' by the control culture (see Miller \& Reilly 1995: 329). On the contrary, Cohen's original definition (1972) did not limit moral panic to people and 'societal values' but also includes a 'condition' or 'episode' and 'interests' (see Ungar 2001). This means moral panics can encompass new sites of anxiety including food, health and the environment. This broader conceptualization also includes a wider scope of actors involved and the emergence of new types of moral entrepreneurs - social movements, NGOs and other advocates - who have expanded the scope of their activities to draw media attention to their particular cause (Cohen 2011). Furthermore, not only have moral panic forms and actors diversified, so too has the relationship to the status quo. Cohen has argued that moral panics are more than expressions of outrage and are not restricted to misrepresentations by elites to reinforce dominant practices through the demonizing outsiders and marginalized groups (2011, also David et al 2011). Lastly, it raises the possibility that the implicit irrationality in the notion of 'panic' can be turned on its head in that what is a rational or irrational response to perceived danger and heightened anxiety is not only constructed but also becomes the subject of debate itself. 
The danger in broadening a concept in this way is that it loses meaning and coherence. This article negotiates this by arguing GM food could be constructed as a moral panic where there is heightened concern or anxiety (Goode \& Ben Yehuda 1994); the stigmatization of individuals, groups or things; risk constructions signify major 'moral disturbance' (Young 2009); and the scare has a 'symptomatic quality' (Garland 2008: 11). Moral here refers both to a loosely defined but strongly held sense of right and wrong as well as the stronger social taboos that may be seen as at risk of violation by cultural and structural changes taking place in society (see Young 2009). Symptomatic is the non-random emergence of a scare that links to deeper, more long-running yet 'associated problems' and 'underlying disturbances' about perceived threats to an 'established value system' (Garland 2008: 11). Thus, what is significant is not the scare itself but how it is constructed by key actors including the media in ways that resonate with 'wider anxieties' about societal transformation and cultural conflicts (Cohen 2000; Young 2009). However these features of heightened societal anxiety and symptomatic qualities could also be said of new risks so what distinguishes a moral panic is the dominance of a moral dimension.

\section{New risk theory}

Traditional new risk conceptualizations emerged out of very different concerns about 'industrial' disasters in the 1980s - Bhopal chemical leak, the Chernobyl nuclear disaster and oil spills - and heightened public anxiety over these. Risk Society theory is premised on the view that society has always been subject to risks that had negative consequences but prior to late modernity they were natural disasters or 'humanity learnt to deal with self-generated uncertainties' (Beck 1999: Xii). New risks are typically constructed as manufactured risks in that they emerge out of the technological advances of late modernity; pose a potential physical threat of potential harm to environment and health; generate radical uncertainty in the form of scientific uncertainty and public uncertainty; and are invisible in that they cannot be detected by naked eye but are pervasive, proximate and everyday life-sustaining elements of air, water, food etc (see Beck 1986). Conflict arises because new risks 'exist only in terms of the ... knowledge about them' so they be 'changed, magnified, dramatized or minimized within knowledge, and to that extent they are particularly open to social definition and construction' and hence the mass media have a central role to play 
(Beck 1986: 23, author's italics). Beck affords the media a central role in the processes of definition and construction. Not only are many of these risks known by the wider society only through media, they are defined and made visible through news and journalists are able to cast a spotlight on the inability of governments to manage these risks given contested science and knowledge limitations (Beck 1986, 2000). Thus the media are critical to the social construction and contestation of risk in late modernity.

Risk Society is a dominant framework in studies of risk and the relationship between this and social change but the inclusion of the media - and their particular logic - in empirical studies has been limited and 'sporadic' (see Tulloch \& Zinn 2011). Part of the problem is that much of Beck's work is at the level of grand theory and has been critiqued by Cottle (1998) for assuming a monolithic media whereas media studies have highlighted an increasingly fragmented and diverse media landscape. Furthermore, Tulloch \& Zinn (2011: 4) have argued that his conception of role of media is 'reductionist' in its neglect of the particular logic which shapes how journalists decide what is news and how production processes shape constructions. The problem with this has been most clearly articulated by Kitzinger (1999) who have highlighted that media do not always engage with risk debates because conflict over uncertain, contested science and unknown effects lend themselves to abstractions whereas journalistic practices tend to emphasize the concrete. However, when the operational challenges of the abstract are overcome media may just as readily support as contest government's constructions of risk.

These are negotiated in this article, first, by adopting a 'soft' constructionist approach in which not only do media construct risks they also construct their role in relation to these, for instance, in revelatory terms. As with moral panic this directs attention to the definers of risk. Second, it draws on the literature on media logic to show how moral panic and new risk discourses were constructed by journalists.

\section{Moral panic and new risks: linear progression, co-existent or convergent discourses}

There has been a proliferation of risk discourses in late modernity (Macdonald 2003), growing media and public concerns about the management of them, the creation of new risk regimes in response to these (see Hood, James \& Scott 2000) as well as a plethora of risk studies. The issue then arises as to whether moral panic is still a 
useful concept in an 'era of acute' environmental and manufactured risk perceptions (Beland 2011: 225). It is in response to these questions provoked in part by the emergence of Risk Society theory that some proponents have broadened the conceptualization of moral panic in ways outlined earlier (for a critique of this see Critcher 2009).

This begs the question as to what is the relationship between moral panics and new risks. Three permutations have been suggested in the literature. Firstly, Ungar initially considered the possibility that 'new sites of social anxiety' associated with new risks 'have emerged alongside moral panics' but then went to argue that rather than co-exist, new risks had supplanted their predecessor because key features of manufactured risks did not 'fit the moral panic paradigm' (Ungar 2001: $271,272,289)$. This implies a linear progression in types of risk that have come to dominate late modernity. Secondly, Hier suggested on the contrary that there had been a 'convergence, not a shift in sites of social anxiety' and that the proliferation of acute and uncontrollable anxieties associated with risk society threats 'do not replace but rather conjoin with the existential anxieties that are endemic to (late) modern thinking' (2011: 9; also 2003). Thirdly, Beland offers a more empiricallyrooted alternative in his comparison of the 1996 BSE/CjD and the 2003 SARS scares (2011). He suggests that 'only some health scares take the form of moralizing, sensational, exaggerated and volatile political episodes known as moral panics ... some health scares may not involve exaggerated moral reports or the emergence of a moral discourse about the collective source of harm' (2011: 225). He concludes that what is needed is 'case-by-case empirical investigation' in order to assess what type of scare is taking place.

This leaves us with the possibility that some scares may not engage the attention of the media at all; others may be constructed by them as neither new risk or moral panic but some other type; some as one or the other; some as co-existing at the same time but in different stories - for example, an major chemical leak could vie with a breaking news story on paedophile ring for the top headlines; and some may include powerful moral discourses and powerful new risk discourses in the same narrative. The latter allows for convergent and contradictory discourses constructing the same risk story so adding energy, intensity and volatility to the politics of a particular scare. This, the article argues, creates a superstorm in which the moral and new risk discourses become mutually reinforcing. Such hybridization 
does not fit with classic or narrow moral panic approaches but it can be readily accommodated by the broader conceptualizations of moral panic theory and by including media logic in new risk theorizations. However ultimately it needs empirical explorations before we begin to theorize which forms emerge in what circumstances, with what implications for social conflict and change and here it is useful to turn to the concept of 'media logic'.

\section{Media logic and the potential for a 'superstorm':}

One of the key critiques Tulloch \& Zinn (2011) make of Risk Society thesis is its neglect of 30 years of work on media logic. This argues media institutions operate according to their own values, beliefs and customs as well as the particular constraints and opportunities presented by different platforms and formats (see Altheide \& Snow 1979) in different countries. The implications of this highlight the contradictions in media engagement with risk.

On the one hand, media do not always engage with risks because of operational difficulties or lack of interest. Hypothetical or futuristic discourses about what might happen and abstract knowledge debates about contested, uncertain science present particular challenges to journalists whose professional practices centre on the here, now and certain (Kitzinger 1997) Furthermore, once media have engaged critically with risk policies any potential they have to disrupt these is undermined by discrepancies between short news cycles and long policy ones, so governments can usually wait for newspaper paroxysms to subside before resuming policy business as usual (see Howarth 2012).

On the other hand, when they do engage with risk debates the issue becomes which media and how. Murdock et al (2003) have highlighted the particularly diverse, fragmented and contradictory nature of the British media however it is newspapers that tend to be most critical in how risk debates evolve. This is partly because British newspapers are not subject to the same regulatory constraints as their broadcasting counterparts so have greater freedom to take sides in a debate. In addition, television has a short-term or immediate agenda-setting role while national newspapers have a primary agenda-setting role in the medium to long term because they have the 'power to set the dominant political agenda' (McNair 2000: 30). 
Newspaper formats - particularly editorials - are better able to accommodate dissenting views on topics for instance with moral panic or new risk type debates (see Altheide 2009). Furthermore British newspapers can take the 'lead in establishing dominant interpretative frameworks' and can serve an 'investigative' or campaigning function 'on the back of which major agenda-setting interventions can be mounted' (McNair, 2000b: 30). Thus the campaigning newspapers can be critical to how a risk debate evolves. When this happens three features are likely to shape coverage. Firstly, if newspapers distrust government handling of risk they are likely to assign credibility to other sources including high profile figures or environmental/consumer NGOs (see Howarth 2012). Secondly, where there are no concrete images of dying birds or BSE-befuddled cows newspapers can make sense of abstract debates about knowledge through associations. As Mairal has observed narratives of risk can be linked to previous situations and events to extract 'lessons to be learnt' and in so doing tap into 'latent' - or active - public memories (2011: 71). Thirdly, discourses of fear are likely to dominate the impact of which creates a sense of disorder and things out of control (Altheide 2009).

\section{Analysis}

This article analyses the presence of two types of risk discourses in newspaper engagement on GM food. Moral panic type discourses are explored through stigmatization, the credibility afforded this by experts as well as the construction and role of moral entrepreneurs in guarding the 'moral barriers' from a flood of GM food. New risk type discourses are examined in claims about 'manufactured' food; radical uncertainty in the nature of knowledge/evidence and the nature of the risk (proximate and invisible); and in the unwillingness of government to act.

It focuses in particular on newspapers primarily because of their distinctive role of newspapers in setting the medium to long term news agenda needed to shape social change. They are also better able to deal with the conflict that characterizes moral panic and new risk debates because they are less constrained than broadcasters in taking an overt policy stance. However one of their key operational limitations is short news cycles and hence a difficulty in sustaining engagement for long enough to influence public debate and social change. Here campaigns can play a significant role. British newspapers have a tradition of 
campaigning on a range of issues. The term 'campaign' is often used loosely to refer to an intensification of media engagement on an issue. However this is a poor definition because it potentially includes both British television and newspapers but the former have a statutory requirement that prevents them from overtly taking sides in a policy debate. In addition, it is possible that newspapers may intensify their coverage but stop short of advocacy (see Howarth 2013) which is what the other national newspapers did with the GM food and crops row. Instead campaigning is used here to refer to the clear formulation by newspapers of their own position in the debate, articulating these most explicitly in editorials, actively advocating policy change and self-labelling the form of engagement. That is, it entails intentionality and high level editorial decision-making informed by a particular media logic that the informal use of the term 'campaigns' does not consider. Operationally formalized campaigns enable newspapers to sustain coverage well beyond relatively short news cycles so have the potential to disrupt longer policy cycles. The empirical advantage of directing the analysis at these campaign discourses is that they are likely to comprise the least equivocal discourses on risk. ${ }^{1}$ In this particular case the four newspapers that launched self-labelled campaigns against GM food policy- the Mirror, Express, Daily Mail and Independent/Independent on Sunday - also represent a cross-section of newspaper formats and demographics and constituted 'some' of the newspapers Tony Blair criticized for their 'campaign of misinformation' (Blair 1999). That is, they were constructed by themselves and politicians as playing a particular role in heightened public awareness or anxiety about GM food and crops.

Campaigns are concerned with sustaining pressure so it is hardly surprising that over 700 news, features and opinion pieces were generated between January 1998 and December 2000 by these four titles. The analysis here focused primarily on editorials but was supplemented with new stories where these were needed for clarity. At one level this is limiting because only $10 \%$ of all articles in this period were editorials and furthermore this presents only one view expressed in a title. Newspapers often include some diverse viewpoints including opinion pieces by experts or high profile figures who may express diametrically opposed views to their own. While this may create the impression of diversity and debate, it is editorial policies that shape the selection of news stories and features as well as the angle taken (see Howarth 2012). Editorials have traditionally provided the most explicit 
articulation of these positions but because there are so many issues covered by the newspaper every day there is intense competition for the coveted slots on the title's editorial column (Firmstone 2008; Eilders 2002). They are thus important signifiers of issues prioritized by the editor within a range of stories selected for coverage that day so also important barometers of a newspapers' engagement with and critical interventions into risk debates. Editorials were analysed in terms of key features of moral panics, of new risks and then the relationship between them.

However before analysing editorial discourses it is first necessary to locate these within the wider social debates of the argumentative context. This is the totality of historical and current discourses and arguments circulating in a society on a particular issue promoted by a variety of agents including NGOs, professional bodies, etc (See Billing 1987, Fairclough 1992). Media and government select discourses from those circulating in the argumentative context - including new risk and moral panic types - with which to make sense of events, take a position in a debate and construct their own argument. So before exploring how newspapers constructed GM food as a moral panic, new risk or both it is first necessary to sketch out the main positions in societal debate.

\section{The argumentative context}

On the one hand, a policy hegemony began to emerge in post-war Britain. After 1945 this centred on scientific farming, the industrialization of food production and food security but during the 1970s and 1980s it expanded into a liberalization of controls and the 'cheap', efficient production of food (Millstone \& Van Zwanenberg 2005). On the other hand, a counter-discourse began to emerge from the 1960s from newly formed environmental NGOs who morally objected to scientific farming. They also increasingly questioned whether the increased use of chemicals was justified given possible, unknown adverse effects on health (see Rootes 2000). These 'moral' and 'effects' arguments were given intellectual weight from 1980s with new theorizations of Risk Society and further 'evidential' weight with a series of food scares in Britain from 1988 and which peaked with the BSE/CjD furore in 1998. This was explicitly constructed by NGOs - consumer and environmental ones - as having resulted from the liberalization of controls and the expansion of scientific farming into new morally questionable areas. It also contributed to a climate of distrust and an unwillingness to trust reassurances based on government science (see Howarth 
2012). This context provided the macro-ideological framework within which two polarized strands of thinking emerged around GM food.

The first strand emerged from the biotechnology industry, EU officials and British ministers around a limited definition of GM food which focused on the end product and viewed the technology as a speeded up extension of natural processes of cross-fertilization (see Genewatch 1999). This explicitly excluded moral questions about splicing genes from one organism and placing them in another. It also underplayed any risk, limited the number of assessments seen as necessary, ruled out a large number of products from labelling as GM food so minimalized the extent of consumer choice and agency. The intention in doing so was to provide enough controls to reassure the public that the food was safe and they had choice over whether to eat it or not but at the same time avoid 'over-regulation' that might hamper the expansion of a strategic technology seen as on a par with nuclear power and ICTs (see Millstone \& Van Zwanenberg 2003). This minimalist position was primarily intended to reassure the public and avoid a stigmatization of the technology rather than because they thought there was any likely harm to health or environment.

A counter-argument to this emerged from environmentalists, consumer groups, European parliamentarians and, from 1999, food retailers based on a broad definition of GM food which emphasized, not on the end product, but the processes of manufacturing. This enabled moral questions about how GM was produced to become important considerations. They also drew on historical parallels with past scares and intellectual arguments about new risk to raise the spectre of unknown effects and possible harm so advocate comprehensive risk assessment of process not product. Moral arguments were not limited to process but extended to issues of consumer 'right' to choose and the need for individual agency in the context of government failures to protect the public over BSE/CjD. This maximalist position argued for comprehensive controls, labelling and choice. However, the moral-harm argument they put forward, despite its potential resonance, did not initially capture the attention of newspaper journalists.

\section{Critical interventions: shifting patterns of newspaper construction of risk}

A discourse analysis of the four campaigning newspapers suggests engagement with GM food was more sporadic and content more fragmentary and contradictory between the launch of GM food in 1996 and June 1998 than has been suggested 
elsewhere (see Bauer 2000). There were no editorials before the intervention of Prince Charles and what limited news coverage there was varied between the unproblematized, the contradictory and the ambivalent. For instance, the Daily Mail treated the claims of GM food proponents about benefits unproblematically and ignored counter-claims of risk or links to other food scares that dominated the news agenda at the time (see Poulter 1998). The Independent on Sunday expressed bemusement at the lack of public debate in the UK on GM food and crops given the intense controversy in Germany (Lean, 1997) but did not feel strongly enough to commit an editorial to the issue before December 1998. The Express and Mirror were ambivalent, including claims about benefits and risks sometimes in the same story (Harrison, 1997; Wilson, 1997). Thus, there was no sense of a coherent or collective newspaper positioning on the novel technology and no clear locating of themselves within the wider debates. This changed with the interventions of Prince Charles and Professor Pusztai in the middle of 1998. Thereafter, newspapers increasingly engaged. They also committed more editorial columns to articulating the title's own views on the risks and how these should be managed; argumentation intensified as editors devoted more space to exploring the issues; and the content of argumentation shifted as discourses of 'moral' threat and 'unknown effects' became more dominant.

\section{Moral panic discourses}

This article has already suggested that moral panics are characterized by stigmatizing discourses that construct 'deviance' in particular ways, accredited experts' give credence to these deviance claims and 'moral entrepreneurs' guard the 'moral barricades' against deviance and argue for action. All three are discernible in the editorials that followed the interventions of Prince Charles and Professor Pusztai in mid-1998.

Stigmatizing discourses were based in claims that scientists were venturing beyond what was morally permissible and in the cultural labels used for GM food. For instance, media coverage of the call by Prince Charles for a halt to genetic 'tinkering with food' emphasized his warning that scientists were straying into 'realms that belong to God and to God alone', his questioning of 'whether society had the right to experiment with, and commercialize the building blocks of life'; and his suggestion the BSE/CjD debacle had highlighted how disregarding the natural order 
has consequences (Kay and Hayes 1998). These discourses evoked a sense that one of the last taboos or moral barriers associated with the essence and sanctity of life was being tampered with for base reasons of profit. These were seen as validated in that they echoed widely held public fears (Express 1998a) and subsequently by the 'preliminary' findings of Pusztai about the compromised immunity of mice. Thus editorials claimed that it was with a 'dread inevitability' that science - in the form of Pusztai's findings - should confirm 'genetically altered food might pose a threat to our health' for the 'vast majority of us had already reached that conclusion based on no greater expertise than the commonsense suspicion that scientists were busily tinkering in areas they did not fully understand' (Daily Mail 1998a). This convergence of lay commonsense with expert science enabled the newspapers to legitimize their increased use of emotive terms such as 'frankenstein foods' as reasonable and rooted in real possibility. 'In a time of all-too frequent scares, the more sober-headed might regard this as hysteria' however 'the latest revelation about the possible effects of this experimental food raises the prospect that scientists might be creating something truly dreadful' (Express 1998b).

Discourses of 'frankenstein foods' thereafter became more prevalent (see Daily Mail 1999a, 1999b, 1999c, 1999d; Daily Mirror 1999b; Independent on Sunday).

The moral barriers are guarded by moral entrepreneurs and there were three in the GM food case. The construction of Prince Charles in these terms rested on moral claims that he was 'right to speak out' (Daily Mail 1998a) because the concerns were legitimate and 'widely shared' fears and because of the reasonableness of his position. For instance, it was claimed that 'all the Prince is arguing for is caution, more research and the possibility of informed consumer choice' (Daily Mail, 1998a). Thus, the media constructed the Prince as a moral entrepreneur who signified the voice of 'ordinary' people despite his formal status, moderation and lay reason and who drew on past history including that of BSE/CjD to arrive at 'commonsense' judgements. The construction of Pusztai as the moral entrepreneur was based on claims in news stories, features and guest columns about his status as an 'independent scientist' of international standing (Express, 1998c) with the courage to raise 'serious doubts' about GM food (Harrison, 1998), 'expose' food risks despite considerable professional and personal cost (Express, 1998d) and willing to make the moral argument that GM food should be tested on laboratory 'guinea pigs' not on the 'general public' (Ingham, 1998). However, the 
most powerful evocation of his moral entrepreneurship lay in editorials claiming that the man 'who carried out the research, has said that if he had the choice, despite all the assurances from food producers and the authorities, he would choose not to eat such foods. However there are no legal requirements for consumers to be warned ... This cannot be right' (The Express 1998b). Thus Pustzai's moral entrepreneurship entailed the conjoining of his expert-consumer and professional-personal discourses with a powerful normative statement of consumer right to know, to choose and to act.

The third set of moral entrepreneurs were the newspapers who launched campaigns rooted in a 'moral' agenda necessitated, they argued, by a government unresponsive to public concerns and unwilling to heed the 'lessons' of BSE/CjD about possible health risks. Ministerial unresponsiveness to public concerns was attributed to a 'disturbing ... political culture' in Whitehall in which 'senior executives from the biotech industry are in the habit of visiting the Ministry of Agriculture on "an almost daily basis" to lobby civil servants for favourable treatment' (Daily Mail 1999b). The consequence was ministers enthusiastically 'intent on ushering in' a new food science despite the lessons of BSE/CjD (Independent on Sunday, 1999a). The tragic lesson was that change should proceed cautiously and development halted pending further research. The government's current approach of proceeding until evidence of harm emerged meant it would be 'rather late to discover that there are malign effects on our health, on our indigenous crop species and on our animal and bird populations' (Independent on Sunday, 1999a). The campaigns could therefore be justified on terms of urgency and government failure to protect the public. They drew on a three part agenda. First, it was to 'bring out the facts behind the food we eat' (Express 1998c). Second it was to 'alert the public to the dangers of genetically modified "Frankenstein" foods' (Daily Mail 1999b; see also Mirror 1999b). Third, it was to advocate the 'Government ... take two important actions on genetically modified food: the first is to declare a three-year freeze on developing modified crops; the second is to insist that all products containing modified food are clearly labelled. The Government appears to have learned nothing from the beef debacle, where much scientific research has failed to disclose the exact nature of any risk'. (Independent on Sunday 1999a). Thus, newspapers constructed their roles as moral entrepreneurs in terms of educative, revelatory and advocacy compelled to act in this way because of government failure to guard the barricades. This was 
legitimized by the interventions of Prince Charles and Pusztai and by the policy failure of government.

\section{New risk discourses}

New risks are typically constructed as manufactured ones that the emerge from the technological advances of late modernity; generate radical uncertainty because they are seen to pose potentially unknown effects to the environment and health; yet the knowledge of them is uncertain; and the risks posed are invisible, pervasive and proximate in everyday life-sustaining elements of air, water, food etc. Government management of these risks is seen to be compromised by the limits of knowledge and by their own complicity in advancing the manufacturing industries of late modernity. Some of the editorials constructed GM food in these terms and thus as a new risk.

Firstly, this was done by locating it within 'the history of manufactured food' and where 'many people already find foods pumped full of steroids, boosted by artificial fertilizers and "protected" by heavy doses of antibiotics a source of deep anxiety ... the history of chemically-drenched "scientific" farming does not inspire confidence' (Daily Mail 1998a). This created the sense of the manufacturing of food as contaminating the natural rather than enhancing it as industry claimed, Contamination went beyond the individual 'modified' or 'engineered' food to include natural foods through association. That is, GM food was 'sold without being adequately marked and that altered and natural foods are mixed in storage, so denying people choice' (Daily Mail 1998a).

Secondly, a particular from of radical uncertainty emerged in discourses of not knowing. Pusztai's research had discovered stunted growth in rats but 'this does not, in itself, prove that it could cause similar damage in people' (Daily Mail, 1998b). The problem with GM food was that 'we simply do not know whether it is safe or not.... We as consumers do not know whose claims to trust' (The Express 1998b) nor do we "have any idea of the extent to which supposedly natural food is in fact genetically altered ... the fact is that we do not really know the possible harm such food might do' (Express 1998b). For the Independent on Sunday the concern arose 'from the law of unintended consequences... who knows what effect changes to the DNA structure of plants might have? The BSE crisis is the salutary demonstration...' of risk (2000a). Thus, not knowing was constructed as the absence of incontrovertible 
evidence of harm or safety, risk or benefit; uncertainty was defined as suspended certainty. The anxiety associated with this was accentuated by the invisible and proximate nature of the risks. Not only were GM ingredients in everyday foods bought in the supermarket it appeared that there was 'danger lurking on every plate' (Express 1999a).

Thirdly, the response of the government was seen as wholly inadequate and not only because of claims about the close relations between ministers and the industry discussed earlier. The management of GM food policy was described as 'shambolic, naive and blithely indifferent to the genuine concerns of millions of British consumers (Daily Mail, 1999b) and the ministers blasé or incompetent. For instance, the food minister 'has responded to this alarm with extraordinary, indeed, alarming, sangfroid' in which he claimed a ban would '"'inappropriate" though he graciously agrees that more testing is necessary. Where's the logic in that? We need the testing because we do not know what the dangers are... If he can't work that out, why is he in the job? (Daily Mail 1999b). The Cabinet Minister in charge of GM food 'has been accused by English Nature of misleading Parliament over its call for a moratorium on the production [of GM crops] ... and condemned by 20 leading international scientists for being 'massively uninformed' about the threat to public health (The Express 1999a). Thus, the newspapers constructed a very powerful new risk discourse which located GM food within other 'manufactured' food risks; generated acute uncertainty in the form of suspended certainty of whether or not they might have harmful effects; and stressed the proximity of the risks through everyday shopping for food.

\section{Convergent moral panic and new risk discourses}

Newspaper editorials thus drew on both moral panic and new risk type constructions to make sense of GM food however what is unclear at this stage is what relationship these discourses had to each other within the same texts. The following permutations are discernible.

Firstly, a small number of texts constructed GM food as a moral threat on its own usually in the context of transgenic developments defined as 'taking genetic material from one species and transplanting it into another' and here they quoted Lord Alton's demand for 'an immediate moratorium on what he called "this grotesque meddling with nature ... [which] had got completely out of hand ... [it] raises a whole 
stack of ethical and moral questions" (Poulter 1999). They also referred to the 'super-salmon' which had been given 'extra growth hormone gene' to facilitate rapid growth and was expected to be available as food shortly (Chapman 1999).

Secondly, a few editorials or news articles constructed GM as a physical threat but made no mention of the moral threat posed. The fear was "superweeds" could be created. ... which are resistant to all sorts of herbicides, or even to completely unpredictable plant mutations' (Arthur 1998).The Express, for instance, claimed that for months it had 'warned of the possible dangers of genetically modified food' and now British Medical Association report 'echoes' these concerns and calls for 'for more detailed researched into the risks of cancer, new allergies and antibiotic resistance. The common practice of using antibiotic genes in GM plants could, says the BMA, lead to increased vulnerability to potentially fatal diseases such as meningitis' (The Express 1999b). The Government's advisory committee on foods had 'predicted that antibiotic-resistant genes in the crops could escape into the environment; and the Royal Society urged a closer look at regulations covering weedkiller- resistant GM crops, to avoid the spawning of superweeds' (Lean, 1999).

Thirdly, most of the editorials and commentaries analysed included both moral panic and new risk type discourses in the same text. For instance, the editorial on the Prince Charles discussed earlier questioned the morality of altering organisms at the level of the gene, 'the building block of life'; included the manufactured risk in claims about 'genetic tinkering' and the idea of 'manmade disasters'; and raised the spectre of unknown effects in the claim that 'the unforeseen consequences which present the greatest cause for concern". (Kay \& Hayes 1998). The claims of the multinational companies that genetic modification 'is a natural and safe process' were challenged in claims that 'it's not natural about taking genes from a fish and putting them in a tomato. Swapping genes between different species breaks nature's own safety barriers' and test results on this type of swap between brazil nut were put into a soya bean 'showed that people with nut allergies were now allergic to the bean' (Lyons 1998). It was these texts constructed around 'moral-plus' and 'effectsplus' discourses which were the most emotive and evocative because they became mutually reinforcing that tapped into underlying disturbances about the moral accountability of science and about a history of meddling with food in ways that meant the ordinary person had to deal with any dangerous consequences aka BSE/CjD. 


\section{The consequences: a 'superstorm' and the argumentative context}

This article conceptualizes a media 'superstorm' in terms of intense, sustained media coverage; social volatility; and policy disruption. Not only did British newspaper engagement with the GM food debate intensify, it exceeded that anywhere else in the world (Bauer 2002). It was also sustained albeit not at the same levels of intensity for 18 months largely due to newspaper campaigns that ran for a year so facilitated newspaper engagement well beyond relatively short news cycles.

The most clearly discernible impacts on the wider society were, first, with newspaper coverage of the Pusztai research. Sales of the first FM food product launched in Europe, a tomato paste, originally outsold conventional varieties by 2: 1 but within days of Pusztai story breaking sales started to fall and retailers explicitly made the link between this and media coverage (see Austin \& Lo 1999). Within a year a de facto consumer boycott had emerged and supermarkets, unable to sell stock, withdrew GM tomato paste from their shelves. Other forms of direct action also increased. Not only did NGO and activist groups trash GM crop trials and storm ships bringing GM soya and maize into the country, relatively unexpected individuals and organizations engaged as well. Organic farmers brought legal suits against Monsanto for putting their crops at risk of contamination. Ordinary shoppers protested outside supermarkets or spray painted cans of GM tomato paste in stores. Local authority canteens, schools and hospitals insisted on GM free food (see Genewatch 2000). That is, public opposition widened, deepened and became prolonged. While some of the protesters had their own networks that kept them informed, many of the shoppers would not have known about GM food risks without media coverage and it was the de facto consumer and retailer boycotts that compelled Government to act.

The government which had long supported GM food specifically and biotechnology generally set up a Cabinet Office to co-ordinate and formulate policy on biotechnology. One of its first tasks was to review the regulatory framework and scientific journals about possible harm and concluded there was no evidence (Cabinet Office 1999). They then announced responsibility for food safety would be devolved to an independent regulator. None of these measures persuaded newspapers that ministers were genuinely concerned about public health and they did not drop their campaigns until the government had announced a voluntary 
moratorium on the cultivation of some forms of GM crops and Tony Blair had conceded that the science underpinning GM food was uncertain.

The more substantial changes were the shift in responsibility for food safety to a new independent regulator. It would not be credible to claim that the media furore brought this about because New Labour's plans for the Food Standards Agency had been drawn up while still in opposition and before the GM food scare erupted. However the furore shaped how the new agency dealt with the media. Not only were documents to be made public but - in an exception to the new freedom of information law - the advice to ministers was to be published. The management at the FSA also sought a different relationship with the media in which they actively engaged with the particularities of media logic (Krebs \& Podger, 2000: 29). This less confrontational, policy-transparent approach was juxtaposed against claims that the 'less balanced coverage' previously had resulted from government failing to 'provide a good information service to journalists' and failing to construct themselves in the minds of journalists 'as reputable source of unbiased information' (Krebs \& Podger, 2000: 30).

A new discourse of 'Science in Society' emerged from a plethora of parliamentary documents and government-funded research into what had gone 'wrong' with GM food debate. Of particular concern was how the public (and media) respond to uncertain science, the differences between individual agency and the imposition of decisions for how people engage with uncertainty and how elites could best communicate uncertain science (House of Lords, 2000). It is beyond the remit of this article to explore this but it does point to wider social changes rendered by GM food row and political concerns over how to manage this.

\section{Findings and conclusion}

This article set out to explore how moral panic and new risk type discourses converged in media constructions of the GM food row. It located this within an argumentative context characterized by highly polarized debate where on the one hand the proponents of GM food (industry and the British Government) sought to exclude moral and new risk type claims in an amoral-benefit argument for the expansion of the new technology. On the other hand the opponents of GM food (environmentalists, consumer organizations and European parliamentarians) sought 
to include moral and new risk type claims in a moral-harm argument that would halt the development pending further research. The nature of this debate and media logic posed two operational obstacles to the type of newspaper engagement which could have implications for social change. Firstly highly abstract debates about the status of knowledge run contrary to journalistic preference for concrete stories and secondly the difficulty of sustaining a critical discourse beyond short news cycles. These operational difficulties may be why initial newspaper coverage was fragmented and periodic.

This changed with two critical interventions. Newspapers responded to these with typical moral panic type of discourses particularized to GM food. Prince Charles, as a moral entrepreneur, signified moral authority, moderation and lay reason speaking out against the breaching of the ultimate taboo by meddling with the 'building blocks' of life, that is, the gene. Pusztai, as moral entrepreneur, signified the expert-consumer whose scientific knowedge warned of the dangers of the new technology, added credence to the commonsense caution of ordinary people and who personally would prefer not to eat it. The conjoining of these was seen by the campaigning newspapers as legitimizing their use of terms such as 'frankenstein foods' which further stigmatized GM. The government's unresponsiveness to these mounting concerns and its apparent complicity with industry, prompted four newspapers to launch campaigns against GM food policy. The campaigning newspapers, as moral entrepreneurs, constructed themselves as public protectors, guarding them against moral and physical threats posed by the new technology and from government inaction. These discourses on their own were highly emotive and evocative but were given added resonance when coupled - often in the same article - with powerful new risk type discourses. The two key links were Pusztai and Government responses. Not only was the scientist constructed as a moral entrepreneur his findings were constructed in archetypical new risk terms. That is, they challenged government assertions that GM food was safe but did not provide incontrovertible evidence of harm. The result was a discourse of suspended certainty exacerbated by the invisible presence of GM ingredients in everyday foodstuffs and the locating of GM within a history of 'manufactured' food and scientific farming which had led to BSE/CjD. This might have been a short, intense interlude in which government waited for media 'hysteria' to subside however the campaigns prevented this happening and were able to tap into existing, deep disturbances in society in 
which they public had become highly sensitized to food issues. Particular conditions included public disquiet at the direction of scientific farming and the liberalization of markets; a decade of food scares including $\mathrm{BSE} / \mathrm{CjD}$; and a distrust of the willingness of the government to act on behalf of consumers and public. The result was a relatively extreme social reaction.

This article has introduced the concept of a media superstorm to refer to sustained, intense coverage in which moral panic and new risk types of scares converge in the same story in highly emotive, evocative and mutually reinforcing discourses. When these resonate with a highly sensitized context the result is acute anxiety, social volatility and the potential for considerable social change. It argued that such an empirical hybridization does not readily fit within classic or narrow moral panic approaches but it can be accommodated within the more recent, broader conceptions and by including considerations of media logic in new risk theorizations. What this approach does is questioned the tendency in risk studies to use either a moral panic or new risk type of framework or to suggest there may have been a linear progression in which new risks have supplanted moral panics. Instead, it confirms more recent suggestions (see Hier 2011 and Beland 2011) that they may in certain circumstances be conjoined. The focus here is on the circumstances in which moral panic and new risk discourses were conjoined. However, in other circumstances scares may not engage the attention of the media at all; others may be constructed as either new risk or moral panic or as another type; and some as coexisting at the same time but in different stories. These need more empirical exploration and theorization than has been possible here. The aim in this paper was to question the tendency towards a prior assumption that scares are moral panic or new risk type..

\section{Bibliography}

Altheide, D.L. and Snow, R.P. (1979) Media Logic. Beverly Hills: Sage.

Altheide, David L. (2009) 'Moral Panic: From Sociological Concept to Public Discourse' Crime Media Culture 5 (79) pp 79-99

Arthur, C. (1999, 7 February). 'Stop GM Foods: What does it mean? How is it done? Is it Safe?' Independent on Sunday. p. 8. 
Austin, A. and Lo, H. (1999). Oral Evidence to House of Commons Science \& Technology Committee Scientific Advisory System: Genetically Modified Food. London: TSO

Bauer, M. W. (2002). 'Controversial Medical and Agri-Food Biotechnology: A

Cultivation Analysis'. Public Understanding of Science. 11 (3) pp. 93-111.

Beck, U. (1986 (1992)). Risk Society: Towards a New Modernity (M. Ritter, Trans.).

Los Angeles, London, New Delhi and Singapore: Sage.

Beck, U. (1999). World Risk Society. Cambridge: Polity Press.

Beland, Daniel (2011) 'The Unhealthy Risk Society: Health Scares and the Politics of Moral Panic' in Hier, S. Panic and the Politics of Anxiety. London and New York: Routlege.

Billig, M. (1987). Arguing and Thinking: a Rhetorical Approach to Social Psychology.

Cambridge: Cambridge University Press.

Blair, T. (1999, 21 February). 'GM Foods - We Stand Firm'. Daily Telegraph. p.21.

Cabinet Office. (1999). Advisory and Regulatory Framework for Biotechnology:

Report from the Government's Review. London: Cabinet Office.

Cohen, S. (1972 (2002)). Folk Devils and Moral Panics: The Creation of the Mods and Rockers. London: Routledge.

Cohen, Stanley. (2011). 'Whose Side Were We On? The Undeclared Politics of Moral Panic Theory'. Crime, Media, Culture. 7 (3) pp 237-243)

Cottle, S. (1998). Ulrich Beck, 'Risk Society' and the Media: a Catastrophic View?' European Journal of Communication. 13 (1) pp. 5-32.

Critcher, C. (2003). Critical Readings: Moral Panics. Buckingham: Open University Press.

Critcher, C. (2011) 'For a Political Economy of Moral Panics'. Crime, Media, Culture. 7 (3) pp 259-275

Daily Mail. (1998a, 08 June). 'Why Prince Charles is Right to Speak Out', p. 8.

Daily Mail. (1998b, 11 August). 'Dangerous Food', p. 10.

Daily Mail (1999a, 4 February). 'Food in the Shadow of Dr Frankenstein'. p. 10.

Daily Mail (1999b, 6 February). 'An Issue of Concern to Every Reader'. p. 12.

Daily Mail (1999c, 17 February). 'Politics, Trust and the Safety of Food'. p.10

Daily Mail (1999d, 15 March). 'Welcome Retreat on Modified Crops'. p. 10.

Daily Mirror. (1999a, 20 January). 'Monster Food Ban', p. 20. 
Daily Mirror. (1999b, 15 February). 'Label Frankenstein Food: Mirror's 'Label it All' Plea', p. 2.

Daily Mirror. (1999c, 15 February). 'Voice of the Mirror: Just Unpalatable', p. 6.

David, Matthew, Rohloff, Amanda, Petley, Julian and Hughes, Jason. (2011) 'The Idea of Moral Panic - Ten Dimensions of Dispute' Crime Media \& Culture 7 (3) pp 215-228

Douglas, M. and Wildavsky, A. (1983). Risk and Culture: An Essay on the Selection of Technological and Environmental Dangers. Berkeley: University of California Press.

Eilders, C. (2002). 'Conflict and Consonance in Media Opinion: Political Positions of Five German Quality Newspapers'. European Journal of Communication. 17 (1) pp. 25-63.

Express. (1998a, 09 June). 'Food Safety's Hard to Swallow', p. 10.

Express. (1998b, 29 June). 'The Hidden Dangers of 'Frankenstein Food”, p. 10.

Express. (1998c, 10 August). 'End Doubts on Food Safety', p. 10.

Express (1998c, 14 August). 'Was Professor Right?' p. 25.

Express. (1999a, 13 February). 'We Must Give a Lead over GM Foods', p. 10.

Express. (1999b, 17 May). 'GM Food: Act Now to Avoid a Bitter Harvest', p. 10.

Fairclough, N. (1992). Discourse and Social Change. Cambridge: Cambridge University Press.

Firmstone, J. (2008). 'The Editorial Production Process and Editorial Values as Influences on the Opinions of the British Press towards Europe'. Journalism Practice. 2 (2) pp. 212-229

Garland, D. ( 2008 ). 'On the Concept of Moral Panic'. Crime Media Culture. 4 : 9 30.

Genewatch. (1998). 'Briefing 1: Genetically Modified Food: Will Labelling Provide Choice?' Lancaster: Genewatch.

Genewatch (2000). 'GM Crops and Food: A Review of Developments in 1999'. Lancaster: Genewatch.

Goode, E. and Ben-Yehuda, N. (1994). Moral Panics: The Social Construction of Deviance. Oxford: Blackwell Publishing.

Hall, S., Critcher, C. Jefferson, T., Clarke, J. and Roberts, B. (1978). Policing the Crisis - Mugging, the State and Law and Order. New York: Holmes and Meier Publishers. 
Harrison, T. (1997, 21 November). 'Baked Genes; Scientists Create Supernosh; Scientists Create Designer Food through Genetic Modification'. Mirror. p. 2. Harrison, T. (1998, 13 August). 'Genetic Crop Scare Scientist Suspended'. Mirror. p. 11.

Hood, C., James, O. and Scott, C. (2000). 'Regulation of Government: Has It Increased, Is It Increasing, Should It Be Diminished?' Public Administration. 78 (2) pp. 283-304.

Hier, S.P. (2011)(eds) Moral Panic and the Politics of Anxiety. London and New York: Routledge

House of Lords Science \& Technology Select Committee (2000). Science and Society._London: TSO.

Howarth, A. (2010). 'Contested Processes, Contested Influence: A Case Study of Genetically Modified Food In Britain'. In Voltmer \& Koch-Baumgarten, K. (ed.) Public Policy and the Mass Media: The Interplay of Mass Communication and Political Decision Making. London: Routledge.

Howarth, Anita. (2012). 'Participatory Politics, Environmental Journalism and Newspaper Campaigns'. Journalism Studies. 13 (2) pp 210-225.

Howarth, Anita (2013) 'The Weakest Link in Existing Studies: Media-Government Risk Interactions'. Journal of Risk Research. Published online August 2012; $16(1$

Ingham, J. (1998, 13 August). 'Professor who Exposed Food Risk is Sacked'. Express. p. 2.

Irwin, A. (2001) Sociology and the Environment: A critical introduction to society, nature and knowledge. London: Polity

Kay, R. and Hayes, D. (1998, 8 June). 'Charles Warns against Genetic Foods: "We Could Face BSE Style Disaster"'. Daily Mail. p. 1.

Kitzinger, J. (1999). 'Researching Risk and the Media'. Health, Risk \& Society. 1 (1) pp. 55-69

Krebs, J. and Podger, G. (2000). Oral Evidence to House of Commons Select Committee on Agriculture and Health. Food Standards. London: TSO.

Independent on Sunday. (1999a, 07 February). 'Act Now on GM', p.24. Independent on Sunday. (1999h, 21 February). 'Just Two Things...', p. 28. Independent on Sunday. (1999i, 14 February). 'Second Helping', p. 28. 
Independent on Sunday (2000, 28 February). 'Mr Blair's Politically Modified Line on GM food is a Welcome U-turn'. p.24.

Lean, G. (1997, 23 November). “ “Designer Gene” Fails Farmers'. Independent on Sunday. p. 10.

Lean, G. (1999, 3 October). 'Consumer Power: The Humbling of a GM Giant'. Independent on Sunday. p. 18

Lyons 1998, Sept 7, Mirror p6

Mairal, G. (2011) 'The history and narrative of risk in the media'. Health Risk \& Society. 13 (1) 65-79

McDonald, M. (2003) Exploring Media Discourses. London: Arnold

McNair, B. (2000). Journalism and Democracy. London: Routledge.

Miller, D. and Reilly, J. (1995). 'Making an Issue of Food Safety: The Media,

Pressure Groups and the Public Sphere'. In D. Maurer and J. Sobal (Eds.)

Eating Agendas: Food, Eating and Nutrition as Social Problems. New York:

Aldine De Gruyter.

Millstone, E. And Van Zwanenberg, P. (2005). BSE: Risk, Science, and Governance. Oxford: Oxford University Press.

Murdock, G., Petts, J. and Horlick-Jones, T. (2003). 'After Amplification: Rethinking the Role of the Media in Risk Communication'. In N. Pidgeon, Kasperson, R. E. and Slovic, P. (ed.) Social Amplification of Risk. London: Cambridge University Press.

Poulter, S. (1998, 6 January). 'Potato that Promises a Lower-Fat Chip'. Daily Mail. p. 11.

Poulter, S. (1999, 16 March). ‘1m Mutant Animals in GM Experiments'. Daily Mail. P. 27.

Reilly, J. and Miller, D. (1995) 'Making an Issue of Food Safety: The Media, Pressure Groups and the Public Sphere' in D. Maurer and J.Sobal (eds.) Eating Agendas: Food, Eating and Nutrition as Social Problems. New York: Aldine De Gruyter.

Rootes, C. A. (2000). 'Environmental Protest in Britain 1988 - 1997'. In B. Seel, Paterson, M. and Doherty, B. (Ed.) Direct Action in British Environmentalism. London: Routledge.

The Grocer. (1998, 25 July). 'Monsanto hit by "pure vitriol”'. p. 1.

Thompson, K. (1998) Moral Panic. London: Routledge. 
Tulloch, J.C. and Zinn, J.O. (2011) 'Editorial: Risk, Health and the Media'. Health, Risk \& Society 13 (1) pp 1-16

Ungar, S. (2001). 'Moral Panic Versus the Risk Society: the Implications of the Changing Sites of Social Anxiety'. British Journal of Sociology. 52(2), 271291.

Wardman, Jamie. (2008) The Constitution of Risk Communication in Advanced Liberal Societies. Risk Analysis. 28 (6) pp. 1619-1637

Wilson, E. (1997, 14 January). 'What are we Really Eating?' Express. pp. 49-50.

Young, Y. (2009). 'Moral Panic: Its Origins in Resistence,

Zinn, J. (2008). Social Theories of Risk and Uncertainty: An Introduction. London: Blackwell.

\footnotetext{
${ }^{1}$ The newspapers that did not formally label their coverage campaigning can be divided into two groups. The first comprise the 'stable mates' of the campaigning newspapers which tended to take the lead from their campaigning counter-parts but were less aggressive in their advocacy. The difference can be attributed to different editors. The second group comprise titles - for instance, the Times and the Telegraph, which tend to have strong pro-business constituencies and were more ambivalent on the arguments for policy change. (see Howarth 2012)
} 